DOI: $10.35619 /$ iiu.v1i10.194

\author{
Чередник Анна \\ викладач кафедри спеціальної освіти \\ Уманського державного педагогічного \\ університету імені Павла Тичини, \\ м.Умань, Україна \\ ORCID: 0000-0002-8021-4708 \\ e-mail: kuchay@ukr.net
}

\title{
КАТЕГОРІЯ «ГОТОВНІСТЬ» В АСПЕКТІ ПІДГОТОВКИ МАЙБУТНЬОГО ВЧИТЕЛЯ-РЕАБІЛІТОЛОГА В УМОВАХ ІНКЛЮЗІЇ
}

\begin{abstract}
Анотація. У статті розкрито категорію «готовність» в аспекті підготовки майбутнього вчителя-реабілітолога в умовах інклюзії. Встановлено, що готовність до педагогічної діяльності розуміється як складне поєднання психічних особливостей і моральних якостей особистості, що складають основу установки майбутнього педагога на усвідомлення функцій педагогічної праці, професійних позицій, оптимальних способів діяльності; співвіднесення своїх здібностей з подоланням труднощів, що виникають під час вирішення професійних завдань і досягнення запланованих результатів. Виокремлено два основні підходи до характеристики поняття «готовність до діяльності»: функціональний (прояв індивідуальних якостей особистості, що забезпечують ефективність і високу результативність професійної діяльності) i особистісний (певний психічний стан індивіда). Готовність педагогів до роботи в умовах інклюзивного навчання розглядається через такі основні види: науковотеоретичний, психологічний, практичний, що узгоджується із методологічними підходами до визначення готовності, які умовно поділено на функціональний (стан психіки (установка), в якому активізуються такі психічні функції, як уміння мобілізувати психічні і фізичні ресурси), особистісний (прояв індивідуальноособистісних якостей, що формуються в результаті підготовки до певного виду діяльності) та особистісно-діяльнісний (динаміка змін у мотиваційній сфері особистості, формування в ній професійно значущих установок, зміна ціннісносмислової структури світосприйняття особистості).
\end{abstract}

Ключові слова: готовність, підготовка, майбутній вчитель-реабілітолог, інклюзія, діти з особливими освітніми потребами.

Постановка проблеми. Реформи у сфері освіти в Україні мають гуманістичну спрямованість, де особливе місце займає інклюзивна освіта осіб 3 особливими освітніми потребами. Інклюзивна освіта - це новий погляд на систему освіти, що відображає гуманність стосовно всіх членів суспільства незалежно від їхніх фізичних, інтелектуальних, національних, расових та інших особливостей. Але, на жаль, не всі педагоги готові до роботи в умовах інклюзивної освіти в існуючих загальноосвітніх школах. Сьогодні педагогічною громадськістю досить широко обговорюється питання про те, який вчитель потрібен школі в контексті роботи 3 дітьми 3 особливими освітніми потребами в умовах інклюзії.

Сучасна соціокультурна ситуація підсилює значущість педагогічної праці, їі гуманістичну спрямованість, розширює сферу діяльності, тому закономірно постає проблема професійної підготовки майбутнього вчителя-реабілітолога до роботи в умовах інклюзивного навчання учнів закладів загальної середньої освіти.

Аналіз останніх досліджень 3 проблеми. Звернення до сучасних педагогічних джерел (В. Бондар, О. Гноєвська, Г. Давиденко, В. Далингер, І. Демченко, І. Кузава, T. Кузьмичева, З. Ленів, Н. Лещій, М. Лук'яненко, О. Мартинщук, С. Миронов, 
М. Назаренко, Н. Савінова, І. Смирнова, А. Хентонен, 3. Шевців, В. Шинкаренко) дає підставу стверджувати, що процес підготовки майбутнього вчителя спеціальної освіти слід розглядати в двох аспектах: в аспекті виховання, освіти і розвитку як особистості (власне підготовка вчителя) i аспекті діяльності вчителя, що виконує певні дії професійного плану (готовність до професійної діяльності).

У фундаментальних психолого-педагогічних дослідженнях (В. Білан, В. Бондар, О.Глушк, А. Гонеєв, О. Канищева, О. Колишкін, К. Кузьмов, О. Мартинчук, С. Миронова, 3. Мищенко, Т. Рублева, В. Синьов, А. Сманцер, І. Хафизулліна, Л. Черніченко, М. Шеремет, Ю. Шумиловська, Т. Янаданова, А. Яцинік) аналізуються різні аспекти готовності майбутніх педагогів до подолання труднощів у навчанні школярів. Діапазон цих труднощів представлений досить широко. Якщо в одних дослідженнях мова йде про шкільну неуспішність, не пов'язану з будь-якою феноменологією певної групи дітей, то в інших - шкільна неуспішність або труднощі в навчанні пов'язуються 3 більш-менш визначеними типологічними групами школярів (діти зі зниженою навчальною успішністю, педагогічно запущені, діти групи ризику, діти із затримкою психічного розвитку тощо).

Мета статті: на основі аналізу категорії «готовність» та «готовність до діяльності» розкрити ключове поняття «готовність майбутніх учителів-реабілітологів до роботи в умовах інклюзивного навчання учнів закладів загальної середньої освіти».

Методи дослідження - теоретичні: аналіз наукових джерел із проблеми дослідження, що дало змогу визначити мету, уточнити сутність поняття «готовність майбутніх учителів-реабілітологів до роботи в умовах інклюзивного навчання учнів закладів загальної середньої освіти».

Виклад основного матеріалу дослідження. Традиційно під час аналізу результативності педагогічної діяльності готовність вчителя-практика приймається за «величину», сформовану на досить високому рівні (Толмачева, 2004).

«Готовність до діяльності - це наявність у суб'єкта образу певної дії і постійної спрямованості на її виконання. Вона включає установку на усвідомлення педагогічної задачі, модель ймовірної поведінки, визначення спеціальних способів діяльності, оцінку своїх можливостей в їх співвідношенні 3 майбутніми труднощами i необхідністю досягнення певного результату» (Сластенин, 1988).

Готовність до педагогічної діяльності розглядається як цілісне утворення, в якому установки, мотиви, ціннісні орієнтації, з одного боку, і знання, вміння і навички, 3 іншого, опосередковують і обумовлюють один одного (Глушко, 2004).

У розумінні І. Кучерявенко, готовність до діяльності визначається через поняття «пильність», «мобілізаційна готовність», «боєздатність», «передстартовий стан», «працездатність» тощо (2011).

В описі змісту поняття «готовність до діяльності» виділяються два основні підходи: функціональний i особистісний (особистісно-діяльнісний). Прихильники особистісного (особистісно-діяльнісного) підходу (Е. Глушко, К. Гудзь, В. Сластьонін, Г. Толмачева, Ю. Шумиловська та ін.) під готовністю розуміють прояв індивідуальних якостей особистості, що забезпечують ефективність і високу результативність професійної діяльності. Прихильниками функціонального підходу $є$ С. Алехіна, А. Демчук, I. Кучерявенко, I. Хафизулліна та інші. Суть функціонального підходу виражається в припущенні, що готовність є певним психічним станом індивіда.

Система професійної готовності педагога, на думку І. Хафизулліної, включає: психологічну готовність, під якою розуміється різний ступінь спрямованості на педагогічну професію, наявність інтересу до роботи і потреби до саморозвитку та самоосвіти; науково-теоретичну готовність, що включає необхідний обсяг психологопедагогічних і спеціальних знань; практичну готовність, яка передбачає наявність сформованих на необхідному рівні професійних умінь і навичок; психофізіологічну і фізичну готовність - наявність відповідних передумов для оволодіння педагогічною 
діяльністю, сформованість професійно-значущих якостей; відповідність стану здоров'я і фізичного розвитку вимогам педагогічної діяльності (2008).

3 позицій системно-функціонального підходу В. Сластьонін виділяє такі рівні професійної готовності майбутнього педагога: психологічна готовність (спрямованість, установки), науково-теоретична готовність (система знань), практична готовність (система педагогічних умінь), психофізіологічна готовність (задатки, здібності майбутнього вчителя), фізична готовність (стан здоров'я), професійна працездатність (1988).

Готовність розглядається О. Канищевою як: психологічна, яка передбачає наявність у суб' єкта образу структури конкретної дії і постійної спрямованості свідомості на їі виконання, науково-теоретична готовність - характеризується певним обсягом знань, необхідних для успішної професійної діяльності, моральна готовність, практична готовність, внутрішня готовність, якості та властивості особистості, потреба, схильність, включеність (2002).

Готовність до реабілітаційної діяльності Л. Федина розглядає як цілісне утворення, що складається 3 взаємозв'язаних компонентів психологічної (взаємопов'язаних особистісних компонентів, де стрижневим $\epsilon$ мотиваційний фактор), педагогічної (готовність до пізнання, освоєння, осмислення), соціальної (ціннісний характер ставлення до реабілітаційної діяльності) складових професійної готовності, виражених конкретними установками (2002).

Е. Лільїн тлумачить готовність вчителя до здійснення корекційно-педагогічної діяльності з учнями загальноосвітньої школи, що зазнають труднощів у навчанні, як інтеграцію властивостей його особистості в складному синтезі спрямованості на освоєння даного виду діяльності (психологічна готовність), а також знань (науковотеоретична готовність) і умінь (практична готовність) у галузі корекційної педагогіки та спеціальної психології (Лильин и Доскин, 1997).

Отже, готовність педагогів до роботи в умовах інклюзивного навчання розглядається через такі основні ії види: науково-теоретичну, психологічну, практичну, що узгоджується iз методологічними підходами до визначення готовності, які умовно поділено на функціональний, особистісний та особистісно-діяльнісний. В якості об'єктивних характеристик науково-теоретичної готовності (А. Демчук, В. Сластьонін, I. Хафизулліна) розглядаються цілі діяльності педагога в інклюзивному навчанні, його структура, коло проблем, що вирішуються педагогом, і виконання ним професійних функцій з метою досягнення бажаного результату.

На наш погляд, науково-теоретична готовність вчителя до такого виду діяльності включає професійні знання, необхідні для компетентної роботи з учнями з особливими освітніми потребами в умовах інклюзивного навчання в закладі загальної середньої освіти.

Аналіз досліджень в галузі професійної підготовки майбутніх педагогівреабілітологів, зокрема до роботи 3 дітьми 3 особливими освітніми потребами, дозволив визначити науково-теоретичну готовність майбутніх учителів-реабілітологів до інклюзивного навчання дітей з особливими освітніми потребами як інтегративне професійно-особистісне утворення, що характеризується наявністю установки, яка передбачає мобілізацію спеціальних знань, умінь і навичок педагога в здійсненні інклюзивного навчання у напрямі реабілітаційно-педагогічної діяльності.

У межах функціонального підходу готовність розглядається як стан психіки (установка), в якому активізуються такі психічні функції, як уміння мобілізувати психічні і фізичні ресурси. Цей напрям досліджує готовність до діяльності як особливий стан психіки, який, будучи сформованим, забезпечує більш високий рівень досягнень у відповідній діяльності. Готовність розглядається як психічний стан, цілісний прояв особистості, що займає проміжне положення між психічними процесами $\mathrm{i}$ властивостями особистості та забезпечує успішність виконання 
професійних завдань, що дає можливість приймати самостійні рішення, створювати творчу атмосферу (Шумиловская, 2011).

Схоже тлумачення подається в психологічному словнику, в якому готовність визначається як психічний стан, передстартова активізація людини, що включає усвідомлення людиною своїх цілей, оцінку наявних умов, визначення найбільш імовірних способів дії; прогнозування мотиваційних, вольових, інтелектуальних зусиль, ймовірності досягнення результату, мобілізацію сил, самонавіювання в досягненні цілей (Психология, 1990).

Психологічну готовність до професійної діяльності науковці (С. Алехіна, Е. Глушко, Н. Забиняк, Г. Толмачева, Д. Узнадзе) характеризують через динаміку змін у мотиваційній сфері особистості, формування в ній професійно значущих установок, зміну ціннісно-смислової структури світосприйняття особистості. Під психологічною готовністю педагога до реалізації інклюзивного підходу в освіті науковці розуміють складне, цілісне, особистісне утворення, що включає сукупність соціальних, моральних, психологічних і професійних якостей та здібностей, які дозволяють на високому мотиваційному рівні забезпечувати можливість результативної діяльності із включення дитини з особливими освітніми потребами до інклюзивного навчання.

У межах особистісно-діяльнісного підходу готовність до діяльності розглядається як прояв індивідуальних, особистісних і суб'єктних особливостей людини в їх цілісності, що забезпечує їй успішність професійної діяльності.

Практична готовність вчителя-реабілітолога до здійснення реабілітаційнопедагогічної діяльності з дітьми з особливими освітніми потребами включає спеціальні уміння та навички з галузі психології, педагогіки та корекційної педагогіки (Забиняк, Лільїн та Шумиловська).

Практичну готовність майбутнього вчителя слід розглядати як стан цілісного суб'єкта (студента), що включає усвідомлені і неусвідомлені установки, моделі вірогідної поведінки, визначення оптимальних способів діяльності, оцінку своїх можливостей відповідно до майбутніх труднощів і необхідності досягнення певного результату у своїй професії (Шумиловская, 2011).

Головною особливістю готовності до професійної діяльності $є$ їі інтеграційний характер, що виявляється у впорядкованості внутрішніх структур, узгодженості основних компонентів особистості професіонала, в стійкості, стабільності і наступності їх функціонування, тобто професійна готовність має ознаки, які свідчать про психологічну єдність, цілісність особистості професіонала, що сприяють продуктивній діяльності (Шумиловская, 2011).

Таким чином, 3 огляду на основні положення соціально-психологічного i педагогічного розуміння готовності, ми виходимо 3 такого визначення поняття: практична готовність майбутнього вчителя-реабілітолога до професійної діяльності це цілісна система стійких характеристик його особистості і діяльності, що забезпечує успішність реалізації реабілітаційно-педагогічної роботи. Проте, незважаючи на значне підвищення інтересу вчених до проблеми навчання в загальноосвітній школі дітей 3 різними відхиленнями у розвитку, професійна готовність вчителя загальноосвітньої школи до інклюзивного навчання цих дітей як педагогічна категорія в науковій літературі представлена недостатньо.

Такі вчені, як С. Алехіна, Т. Бугеря, К. Гудзь, Т. Дегтяренко, А. Демчук, I. Кучерявенко, Н. Малярчук, 3. Мовкебаєва, Г. Толмачева, Л. Федіна, В. Хитрюк, Т. Четверикова та ін., готовність вчителів до роботи 3 дітьми з особливими освітніми потребами переважно досліджують 3 метою виявлення їхнього ставлення до інклюзивної освіти, а також визначення впливу програм професійної підготовки педагогів у закладах вищої освіти на їхню готовність до реалізації інклюзивної освіти.

У своєму дослідженні К. Гудзь визначає готовність учителів до роботи в умовах інклюзивної освіти як комплекс гармонійно-взаємодіючих і взаємодоповнюючих психологічних та професійних якостей, що дозволяють здійснювати педагогічну 
діяльність на високому мотиваційно-ціннісному рівні і організовувати освітній процес із школярами з урахуванням вимог інклюзивної освіти (2018.)

Готовність майбутніх учителів до роботи з учнями в умовах інклюзивної освіти Ю. Шумиловська визначає як сукупність знань і уявлень про особливості учнів 3 обмеженими можливостями здоров'я, володіння способами і прийомами роботи 3 цими учнями в умовах інклюзивної освіти, а також сформованість певних особистісних якостей, що забезпечують стійку мотивацію до цієї діяльності (2011).

Під готовністю до реабілітаційної діяльності Л. Федина розуміє неодмінну складову частину професійної діяльності педагога, інтегральне утворення, що характеризується загальною гуманістичною установкою педагога, потребою в наданні допомоги i підтримки дезадаптованим дітям, вміннями створювати ситуації реабілітації, інтегрувати знання, проводити психологічний аналіз, відбирати і використовувати засоби реабілітаційної діяльності, прогнозувати ситуації успіху (2002).

В. Хитрюк визначає «інклюзивну готовність» як складну інтегральну суб'єктну якість особистості, яка змістовно розкривається через комплекс компетенцій i визначальну можливість ефективної професійно-педагогічної діяльності в актуальних умовах (2012).

Під інклюзивною готовністю В. Далингер розуміє стійку властивість особистості, що $є$ суттєвою передумовою до навчання дітей $з$ особливими освітніми потребами і характеризується особистісною спрямованістю майбутніх педагогів на реалізацію принципів «включеної» освіти у своїй професійній діяльності (2017).

На наш погляд, категорії «професійна готовність» i «професійна компетентність» близькі, але не тотожні. Готовність - характеристика потенційного стану, що дозволяє педагогу розвиватися в професійному відношенні, а компетентність може проявлятися тільки в реальній діяльності, переходячи 3 внутрішнього плану на зовнішній. Компетентність - категорія оцінна, що характеризує фахівця як суб'єкта певної діяльності, стійка здатність до діяльності зі знанням справи. Під здатністю І. Хафизулліна розуміє індивідуально-психологічні особливості особистості, що $є$ умовою успішного виконання певної діяльності. Під професійною компетентністю пропонує розуміти здатність ефективно вирішувати практичні завдання в реальній професійній діяльності (2008).

Тут доцільно уточнити, що професійна компетентність розглядається як індивідуально-інтегральна характеристика суб'єкта діяльності, що проходить два етапи процесу формування: на етапі навчання - це теоретична готовність до професійної діяльності, а безпосередньо в процесі діяльності - практична готовність і здатність практичного здійснення діяльності.

Низка дослідників (В. Далингер, І. Хафизулліна) розглядають інклюзивну компетентність вчителів як інтегративне особистісне утворення, яке обумовлює здатність здійснювати професійні функції в процесі інклюзивного навчання, враховуючи різні освітні потреби учнів і забезпечуючи включення дитини 3 обмеженими можливостями здоров'я в середовище закладу загальної середньої освіти, створюючи умови для іiї розвитку і саморозвитку $(2008,2017)$.

Отже, під готовністю майбутніх учителів-реабілітологів до роботи в умовах інклюзивного навчання учнів закладів загальної середньої освіти розумітимемо інтегроване особистісне новоутворення, що характеризується синтезом теоретичних знань, компетентностей, практичних умінь і навичок, особистісно значущих та професійно важливих якостей, необхідних для успішної реабілітаційно-педагогічної діяльності, i здатності послуговуватися ними для вирішення стандартних i нестандартних педагогічних ситуацій та проблем, пов'язаних із інклюзивним навчанням дітей 3 особливими освітніми потребами в закладі загальної середньої освіти.

Висновки і перспективи подальших розвідок. Отже, на основі аналізу категорії «готовність» та «готовність до діяльності», поняття «готовність до педагогічної 
діяльності» розуміється як складне поєднання психічних особливостей і моральних якостей особистості, що складають основу установки майбутнього педагога на усвідомлення функцій педагогічної праці, професійних позицій, оптимальних способів діяльності; співвіднесення своїх здібностей з подоланням труднощів, що виникають під час вирішення професійних завдань і досягнення запланованих результатів. Виділено два основні підходи до характеристики поняття «готовність до діяльності»: функціональний (прояв індивідуальних якостей особистості, що забезпечують ефективність і високу результативність професійної діяльності) і особистісний (певний психічний стан індивіда). Готовність педагогів до роботи в умовах інклюзивного навчання розглядається через такі основні види: науково-теоретичний, психологічний, практичний, що узгоджується із методологічними підходами до визначення готовності, які умовно поділено на функціональний (стан психіки (установка), в якому активізуються такі психічні функції, як уміння мобілізувати психічні і фізичні ресурси), особистісний (прояв індивідуально-особистісних якостей, що формуються в результаті підготовки до певного виду діяльності) та особистісно-діяльнісний (динаміка змін у мотиваційній сфері особистості, формування в ній професійно значущих установок, зміна ціннісно-смислової структури світосприйняття особистості).

\section{СПИСОК ВИКОРИСТАНИХ ДЖЕРЕЛ}

Толмачева, Г. (2004). Формирование готовности учителей к обучению детей с задержкой психического развития в общеобразовательной школе: Кандидат педагогических наук. Рязань.

Сластенин, В. (1988). Профессиональная готовность учителя к воспитательной работе: содержание, структура, функционирование. Профессиональная подготовка педагога: сб. науч. тр. Москва: [б. и.]. с. 14-28.

Глушко, Е. (2004). Подготовка будущих учителей к коррекиионной работе с учащимися в условиях педагогического колледжа. Кандидат педагогических наук. Ростов-на-Дону.

Кучерявенко, И. (2011). Проблема психологической готовности к профессиональной деятельности. Молодой ученый. № 12, Т. 2. с. 60-62.

Хафизуллина, И. (2008). Формирование инклюзивной компетентности будущих учителей в процессе профессиональной підготовки. Кандидат педагогических наук. Астрахань.

Канищева, Е. (2002). Подготовка будущего учителя $\kappa$ коррекционнопедагогическои деятельности с детьми, испытывающими трудности в обучении: Кандидат педагогических наук. Курск.

Федина, Л. (2002). Организационно-педагогические условия формирования готовности учителя к реабилитационной деятельности в системе повышения квалификаиии. Кандидат педагогических наук. Тобольск.

Лильин, Е. и Доскин, В. (1997). Детская реабилитология (избранные очерки). Москва: Издательский центр МБН.

Шумиловская Ю. (2011). Подготовка будущего учителя к работе с учащимися 8 условиях инклюзивного образования. Кандидат педагогических наук. Шуя.

Психология: словарь (1990). / под ред. А. В. Петровского, М. Г. Ярошевского. 2-е изд. Москва: Политиздат.

Гудзь, К. (2018). Готовність педагога до роботи в умовах інклюзивної освіти ЗНЗ. Педагогічний часопис Волині.№ 1. с. 128-133.

Хитрюк, В. (2012). Инклюзивная готовность как этап формирования инклюзивной культуры педагога: структурно-уровневый анализ. Вестник Брянского государственного университета. № 1. с. 80-84

Далингер, В. (2017). Подготовка будущих педагогов к профессиональной деятельности в услових инклюзивного образования. Международный журнал 
экспериментального образования. № 2. с. 27-30.

\section{REFERENCES}

Tolmacheva, H. (2004). Formirovaniye gotovnosti uchiteley $k$ obucheniyu detey $s$ zaderzhkoy psykhicheskogo razvitiya v obshcheobrazovatelnoy shkole [Formation Teachers' Readiness to Teach Children with Mental Retardation in a Comprehensive School]. Kandidat pedagogicheskikh nauk. Ryazan. (in Russian)

Slastenin, V. (1988). Professionalnaya gotovnost uchitelya k vospitatelnoy rabote: soderzhaniye, struktura, funktsionirovaniye [Teacher's Professional Readiness for Educational Work: Content, Structure, Functioning]. Professionalnaya podgotovka pedagoga: sb. nauch. tr. Moskva: [b. y.]. s. 14-28. (in Russian)

Glushko, E. (2004). Podgotovka budushchikh uchiteley $k$ korrektsyonnoy rabote $s$ uchashchimisya $v$ usloviyakh pedagogicheskogo kolledzha [Preparation of Future Teachers for Correctional Work with Students in the Conditions of Teacher's College]. Kandidat pedagogicheskikh nauk. Rostov-na-Donu. (in Russian)

Kucheryavenko, Y. (2011). Problema psikhologicheskoy gotovnosti k professionalnoy deyatelnosti [The Problem of Psychological Readiness for Professional Activity]. Molodoy uchenyy. No 12, T. 2. s. 60-62. (in Russian)

Khafizullina, Y. (2008). Formirovaniye inklyuzivnoy kompetentnosti budushchikh uchiteley $v$ protsesse professionalnoy pidgotovky [Formation of Inclusive Competence of Future Teachers in the Process of Vocational Ttraining]. Kandidat pedagogicheskikh nauk. Astrakhan. (in Russian)

Kanishcheva, E. (2002). Podgotovka budushchego uchitelya $k$ korrektsyonnopedagogicheskoy deyatelnosti s detmi, ispytyvayushchimi trudnosti v obucheniy [Preparation the Future Teacher for Correctional and Pedagogical Activities with Children Experiencing Learning Difficulties]. Kandidat pedagogicheskikh nauk. Kursk. (in Russian)

Fedina, L. (2002). Organizatsyonno-pedagogicheskiye usloviya formirovaniya gotovnosti uchitelya $k$ reabilitatsyonnoy deyatelnosti $v$ sisteme povysheniya kvalifikatsyy [Organizational and Pedagogical Conditions of Forming Teacher's Readiness for Rehabilitation Activities in the System of Advanced Training]. Kandidat pedagogicheskikh nauk. Tobolsk. (in Russian)

Lilin, E., Doskin V. (1997). Detskaya reabilitologiya [Pediatric Rehabilitation] (izbrannyye ocherki). Moskva: Izdatelskiy tsentr MBN. (in Russian)

Psikhologiya: slovar [Psychology: dictionary] / pod red. A. V. Petrovskogo, M. H. Yaroshevskogo. 2-e izd. Moskva: Politizdat, 1990. (in Russian)

Hudz, K. (2018). Hotovnist pedahoha do roboty v umovakh inklyuzyvnoyi os vity ZNZ [The Teacher's Willingness to Work in the Context of Inclusive Education at the ZNZ.]. Pedahohichnyi chasopys Volyni. No 1. s. 128-133.

Khitryuk, V. (2012). Inklyuzivnaya gotovnost kak étap formirovaniya inklyuzivnoy kultury pedagoga: strukturno-urovnevyy analiz [Inclusive Readiness as a Stage of Formation of an Inclusive Teacher Culture: a Structural-level Analysis]. Vestnik Bryanskogo gosudarstvennogo universiteta. No 1. s. 80-84. (in Russian)

Dalinger, V. (2017). Podgotovka budushchikh pedagogov k professionalnoy deyatelnosti v usloviyakh inklyuzivnogo obrazovaniya [Preparing Future Teachers for Professional Work in Inclusive Education]. Mezhdunarodnyy zhurnal éksperimentalnogo obrazovaniya. No 2. s. 27-30. (in Russian) 


\title{
"READINESS" CATEGORY IN THE ASPECT OF PREPARATION OF A FUTURE REHABILITOLOGIST IN AN INCLUSION CONDITIONS
}

\author{
Anna Cherednyk \\ Lecturer at the Department of Special education, \\ Uman PavloTychyna State Pedagogical University, \\ Uman, Ukraine \\ ORCID: 0000-0002-8021-4708 \\ e-mail: kuchay@ukr.net
}

\begin{abstract}
The article describes the category of "readiness" in the aspect of preparation of the future rehabilitation teacher in the conditions of inclusion. It is established that in spite of different approaches to the concept of readiness, it is considered as a prerequisite for any successful human activity, readiness for pedagogical activity is understood as a complex combination of mental characteristics and moral qualities of the individual, which form the basis of setting the future teacher on the awareness of the functions of pedagogical work positions, optimal ways of activity; correlation of their abilities with overcoming the difficulties that arise in solving professional tasks and achieving the planned results.

In describing the content of the term "readiness for activity" there are two main approaches: functional (the manifestation of individual qualities of the individual, ensuring the efficiency and high efficiency of professional activity) and the personal (a certain mental state of the individual).

It is revealed that teachers' readiness to work in the conditions of inclusive learning is considered through its main types: scientific-theoretical, psychological, practical, which is consistent with methodological approaches to determining readiness, which are conditionally divided into functional, personal and personal-activity. It is established that on the basis of personal approach, readiness is defined as a manifestation of individual-personal qualities that are formed as a result of preparation for a certain type of activity, which is the basis of scientific-theoretical readiness. In the functional approach, readiness is seen as a state of mind (setting) in which such mental functions as the ability to mobilize mental and physical resources are activated. Psychological readiness for professional activity is characterized by the dynamics of changes in the motivational sphere of the individual, the formation in it of professionally meaningful attitudes, the change of the value-semantic structure of the world perception of the individual.

It is proved that the readiness of future rehabilitation teachers to work in the conditions of inclusive education of pupils of general educational institutions should be understood as an integrated personal neoplasm, characterized by the synthesis of theoretical knowledge, practical skills and competences, personally important and professionally important and the ability to use them to address standard and non-standard pedagogical situations and problems related to inclusive studying children with special educational needs in a comprehensive educational institution.
\end{abstract}

Keywords: readiness, preparation, future rehabilitation teacher, inclusion, children with special educational needs.

Стаття надійшла до редакиії 08.10.2019 р. 